\section{快速城镇化背景下的城中村与老旧小区改造 URBAN RENEWAL IN CONTEXT OF RAPID URBANIZATION}

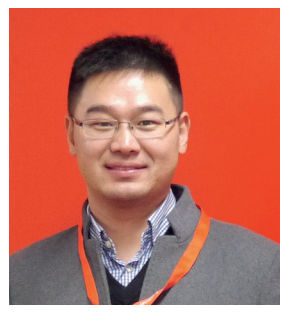

余猛

中国城市规划设计研究院 副所长、高级城市规划师

Meng YU

Deputy Department Director, China Academy of Urban Planning and Design; Senio Urban Planner
摘要

在中国快速城镇化的背景下, 大多数城市呈现出品质不高、特 色不明显、生态环境有待改善、公共服务水平有待提高等现状。但 处在不同阶段, 具备不同发展条件和规模的城市所面临的问题也有 所差异。该访谈首先以存量空间的品质提升为例, 从政府、规划师 组织引导及技术创新、模式创新等多个方向阐述了现状进展及解决 方案。随后针对新城和城市副中心的建立, 进一步阐释了城市发展 的客观规律, 并强调了将城市要素放在区域中统筹考虑的重要性。 在谈及城市更新过程中的城中村拆一建及老旧小区改造时, 受访者 表示, 虽然二者面临的难点互有异同, 但对多元主体间共识的重视 度均有所提升。

\section{关键词}

城市病；城中村；老旧小区；公众参与；城市更新

\section{ABSTRACT}

Currently, in China, rapid urbanization has caused many urban issues including lack of quality urban spaces and distinctive urban identity, declined ecological environment, and insufficient public services. Besides, these problems are increasingly complicated due to the different stages and conditions of urban development and different city scales. This interview starts with the topic of how to improve living quality of existing urban spaces, and Meng Yu, the interviewee, expounds the current situation, progress, and solutions regarding governmental guidance and urban planners' intervention, and the innovations in technology and mechanism. Then Yu elucidates the evolutional laws of urban growth and the necessity of establishing new towns and sub-centers of metropolises, emphasizing the significance of integrating and coordinating different city functions at a regional scale as well. The interviewee also stresses that despite varying difficulties in both demolition of urban villages and renewal of old residential areas, the consensus among plural agents will play an increasingly weighted role in future China.

\section{KEY WORDS}

Urban Problems; Urban Village; Old Residential Area; Public Engagement; Urban Renewal

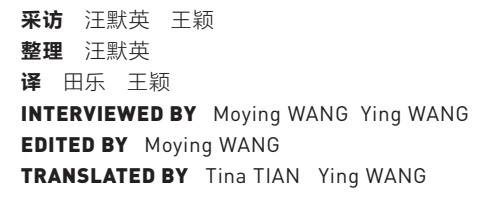




\section{您认为当前中国存在哪些城市病？基于 不同的城市病可以提出哪些解决措施?}

余猛（以下简称余）：中国的城市大都 存在品质不高、特色不明显、生态环境有待 改善、服务水平有待提高等问题。但处在不 同阶段，具有不同发展条件和规模的城市所 面临的问题也有所差异。如从人口城镇化的 态势来看, 其总体呈现 “两头大、中间小” 的特征, 即省会及以上城市、县城人口集聚 较多, 而普通地级市人口大多增长乏力。与 此同时, 省会及以上城市主要面临人口密度 过高、道路拥堵、环境恶化、基本公共服务 不足等问题; 县城的主要问题则在于基本公 共服务不足和以房地产为主导的城镇化对城 镇可持续增长带来的挑战等; 而地级市则在 培育新时期的动力机制、提升城市集聚能力 方面有待加强。

优化城市空间和功能布局、推动人口 疏解、减量、增绿、提质等都是解决城市病 的重要手段。以提质为例, 存量空间正面临 严峻的挑战。现阶段的存量更新主要集中在 低效空间、灰色空间的释放和活化, 碎片化 空间关系的重建，以及在保持空间原有功能 不变的情况下对其形式进行更新。此外，于 2016年提出的开放街区规划理念旨在促使以 居住小区和单个家庭为核心的城市生活模式 回归到以街道为核心。我们往往认为欧洲的 窄街道和沿街住宅的形式并不适用于中国高 密度的人口，但其实已经有研究表明，就综 合容量而言，欧洲地区6层以下密集的沿街住
宅和中国呈点状分布的高层住宅不相上下, 但前者宜人的街道空间尺度却使城市更具人 情味。规划师亟需转变思路, 在居住区的建 设形态和模式上加以反思。值得重视的是, 除政府或规划师牵头外，技术创新、模式创 新也为解决城市病提供了新的方向。比如共 享单车解决了出行最后一公里的问题, 使城 市公共交通能够实现点到点之间各种交通方 式的接驳, 待其成熟运营后, 道路上的机动 车行驶量将得到有效控制。

此外, 我们还要对城市病治理秉持理性 的认知。许多欧洲国家历经了 200 余年才将城 市整治为如今这般干净整洁, 而这一过程我 们只用了几十年, 难免存在疏漏和需要补救 的地方。当前正在进行的生态修复与城市修 补、雾皬治理等举措都有助于城市品质的不 断提升。从历史角度来看, 城市发展的每个 阶段都有其特殊的需求和出发点, 我们需要 尊重和正视城市的发展规律，而非一味否定 或抨击之前的规划设计。在发展理念和技术 手段不断更新的当下，只要我们重视治理， 很多城市问题将有望逐步解决。

\section{城市副中心和新城的建设在缓解城市病} 方面起到了哪些作用?

余: 很多城市问题难以在城市本身的层 面加以解决，而需要放在区域尺度下进行思 考。从城市向大都市区、城市群演变是城市 发展的客观规律，同时也响应了以城镇群为 主体形态推动城镇化的国家战略。 
以北京市为例, 其原先过于庞杂的城 市职能带来了诸多问题。北京被定位为全国 政治中心、文化中心、国际交往中心和科技 创新中心, 若要强化这些核心功能, 就需要 将其他非核心功能向外迁移。北京当前对于 城市功能的 “外疏” 反映了大国首都开始走 向自我功能完善和提升的过程, 也响应了从 城市向城市群转变的趋势, 能够进一步推动 京津冀地区的协同发展。亚洲国家的城市普 遍存在金字塔式的层级结构, 在这种行政区 划模式下, 无论在首都和核心城市周边建立 多少新城或副中心, 其强大的吸引力都始终 存在。因此, 像北京这样的大城市需要有所 为、有所不为, 将一些要素放在区域尺度中 统筹考虑。但我们需要意识到, 城市功能的 重构必然会带来人口结构的变化, 需要在摸 清城市动力、特点和现象之后, 针对城市发 展需要、不同人群的细分需求辅以适当的政 策加以引导。

城中村改造目前面临的最大难点是什 么? 近几年, 城中村的 “拆一建” 政策发生 了哪些变化?

余: 城中村是在中国快速的土地城镇 化现状下形成的一种现象。部分城中村的土 地性质、产权性质和居民的户口性质仍然是 村, 这种限制是现阶段城中村改造的最大阻 碍。但在目前的土地制度下, 要把集体用地 变成国有用地成本很高, 且容易激化社会矛 盾。同时村民户口性质的转变也并非易事:
从村民角度出发, 农村户口可以得到分配的 土地, 很多村民并不愿意转户; 从政府的角 度出发, 将农村户口转为城镇户口需要负担包 括社保在内的巨大经济成本。

此前, 我们并未意识到城中村这类低 成本空间对于初人城市的外来者的重要性, 及其在一座包容性的城市中所扮演的角色。 而随着房地产市场逐渐走向低迷, 土地财政 本身的驱动力也已大不如前。如今, 渐进式 更新正在逐步取代以往整体替代式的更新方 式, 在城中村的拆和建中, 多元主体间的共 识已越来越受到重视。

城中村渐进式更新的首要挑战在于由脏 乱无序、消防安全隐患, 以及人口流动性较 大等因素带来的社会管理和社会安全问题。因 此, 我们一方面要关注物质性要素, 如对房屋 进行加固和更新, 拆除违建, 完善消防、管网 等基础设施; 另一方面也要重视面向多元人群 的社区建设。其次, 要基于功能和新需求确定 改造方向, 形成土地政策层面上的突破。比 如通过保留部分拆后土地的集体用地性质, 由镇政府统一运营, 并在其上新建创新创 业社区、创新创业中心等, 以实现低成本 空间对创新创业孕育阶段的重要支撑。

至于对于记忆的保留, 当前往往只停留 在规划师和城市设计师的情怀层面, 如何将 这种情怀同城中村居民迫切的物质需求相结 合, 仍有待探索更加切实可行的技术手段。

城市中老旧小区的改造有哪些难点和尤 其值得设计师反思的方面?
余：我认为老旧小区改造的难点可以总 结为以下三点:

其一, 老旧小区的人口结构和社会关系 复杂。以北京市中心城区的一些老旧小区为 例, 其居民主要为老年人和初人城市的年轻 白领, 这两类人群既存在年龄的差异, 也有 本地居民与外来居民的差别, 如何协调二者 的不同需求成为一大挑战。现在已有一些值 得借鉴的做法: 比如建造社区食堂, 为腿脚 不灵便的老年人和工作繁忙的年轻白领解决 就餐问题; 以及推广存在于老年人和年轻人 之间的社区互助和存在于老年人之间的养老 互助等模式。养老互助目前提出了积分制的 新形式, 即帮忙照看更加年长的人就能获得 积分, 并在自己需要照顾时凭积分得到相应 的帮助。

其二, 老旧小区中往往存在复杂的产权 问题。大多数老旧小区起初均由单位建造, 经过住房改革后, 产权归属类型复杂, 存在 职工私有、单位公有、单位和职工共同持有 等多种情况, 进一步加大了改造的难度。运 营管理的过程也存在问题, 比如部分老旧小 区的维护管理工作仍由单位负责, 房子一旦 被转卖给他人, 改造费由谁出、改造后的利 益归谁所有等一系列问题便会接踵而至, 进 而需要耗费大量精力进行协调。此外, 还有 部分老旧小区的原单位已经撤销, 后续管理 和配套设施更新难以为继。

其三, 老旧小区的改造机制也亟需突 破。有些小区的改造对新增公共服务设施、 提高绿地率需求迫切, 但在投资平衡角度下 
对容积率有一定要求, 二者之间很难两全; 此外，如果小区居民原地回迁，则会涉及在 外租房动迁补贴等费用, 单纯依靠政府投人 很难支撑大量的更新项目，因而需要与其他项 目捆绑在更大的区域内统筹考虑。

在老旧小区改造的过程中，居民的参 与程度如何? 如何真实地反映当地居民的意 愿、切实满足他们的需求?

余：随着国民经济水平的提高，公众对 公共事务的关心程度逐步提升一一近几年到 各地规划展览馆参观的人数越来越多就是很 好的佐证。此外, 公众的认知也更加理性, 政府处理问题的手段也更加灵活和柔性。在 彼此尊重、理解的前提下, 多元主体间的交 流更加深人。总体而言, 国内社区改造的 公众参与程度正在不断提高, 成效也愈发 显著。

结合近几年的实践经验，我认为公众参 与程度的高低主要取决于组织公众参与的方 式, 我们需要由 “单向式的结果告知” 转向 “全过程的共同缔造”。公共参与并不是张 贴一张布告, 以居高临下的姿态告知公众。 真正由公众深度参与的社区改造往往需要很 长的筹备时间。

首先, 要选择适合的话题和切人方式以 调动居民的积极性。例如, 我们经常以儿童 画作征集或网络论坛话题讨论的形式来鼓励 居民描述其心目中的城市, 这种城市层面的 公众参与方式同样可以推导到社区层面中。
其次, 需要和居民建立起基本的信任, 充分了解他们的意愿和行为习惯。当然, 建 立信任的方式并非不断向居民传达 “我是为 了你好”, 而是要告诉他们 “我们一起来把 这件事做好”。现在北京及很多其他省市都 在推行社区和街道责任规划师制度, 以建立 起长期的点对点联系, 有助于巩固信任并开 展更具规划性、系统性的改造工作。

再者, 还需要更加重视社区治理模式的 创新。和谐积极的社区氛围有助于推动老旧 小区的改造与更新, 将很多复杂问题变得相 对简单、直接。原先普遍存在的居民委员会 是我国独特的社会治理模式, 其成功经验十 分值得借鉴。不同于如今由利益主体构成的 业主委员会、物业委员会，居民委员会是一 种以社会职能为主导的组织, 在社区网络构 建和社区治理中扮演着核心角色, 其所具有 的关系网的约束力也比当前的很多其他方式 更加有效。LAF 


\section{What do you think the urban problems are in China? How to develop different} solutions to deal with specific problems?

Meng YU (YU hereafter): Generally speaking, nowadays many Chinese cities are confronted with issues including the lack of quality urban spaces and distinctive urban identity, declined ecological environments, and insufficient public services. Besides, these problems are increasingly complicated due to the different stages and conditions of urban development and different city scales. For instance, China's population urbanization is characterized for its hourglass structure: a larger population is centered in metropolises (because there are more job opportunities) and towns or villages (because of farmerfriendly policies), while middle-scale cities lacking labor source. Meanwhile, in those mega cities, population migration brings problems like high population density, congested traffic, environmental degradation, and inadequate supporting infrastructures and public services, and small towns are facing challenges of lacking public services and disadvantages coming with real estate-oriented developments. In contrast, middle-scale cities, in between the larger cities and smaller towns, are to be further developed prioritizing in building city identity and attracting population migration.

Planning solutions to these urban problems include the optimization of urban spaces and their functions, population decentralization, construction reduction, green space creation, and urban renewal. Urban renewal, for instance, centers on activating underused spaces, transforming grey spaces, reconnecting fragmented spaces, and regenerating new spatial forms to meet contemporary demands while continuing the original functions. Moreover, the Open Block policy proposed by the central government in 2016 is another strategy which encourages neighborhood-based urban life. Recent research has been proved that the capacity of an area of the high-density housing (of six or less stories) along street sides in Europe almost equals to that of an area of scattered high-rise housing in China, while the former is more livable, which necessitates a prompt change of the construction pattern of residential areas in China. It is worth noticing that, besides governmental guidance and intervention by urban planners, innovations in technology and mechanism are also significant to solving urban problems. For example, sharing bicycles, which have helped better connect different types of transportation modes, may effectively alleviate traffic congestion.

Taken all these problems and solutions into consideration, we should consider the process of urban problem management dialectically. As China is undergoing a rapid urban construction in dozens of years, a much shorter time compared with many European countries with an urban development history of over 200 years, deficiencies and problems are inevitable. Fortunately, we have made efforts to address these problems, including ecological restoration, urban remediation, and haze control. We should examine the current Chinese urban development through a historical lens and try to respond to the urban problems positively, rather than simply deny it. The rapidly improving technologies and innovations make me confident that all urban problems can be solved if enough attention is paid and efforts are made.

How could the construction of subcenters of metropolises and new towns alleviate urban problems?

YU: Although urban problems occur in cities, many of them should be addressed at a regional scale. If we review the evolution process of how a city is developed into a metropolis and 
then becomes part of a greater urban agglomeration, the trajectory shows the law of urban growth and the necessity of taking urban agglomeration as an engine to China's urbanization at a national scale.

Beijing, a typical metropolis worldwidely, has suffered from many urban problems due to its overloaded functions. To enhance its role as China's political, cultural, international exchange, and scientific and technological innovation center, the central government determined to detach the non-core functions of Beijing to surrounding cities. This process of non-core function migration will not only facilitate the urban improvement of Beijing as the capital, but also further promote the collaborative development of the Beijing-Tianjin-Hebei region. Due to the pyramid administrative pattern, normally seen in China and other Asian countries, the construction of new towns and sub-centers will never attenuate a metropolis like Beijing to attract people to live, to work, and to migrate. Therefore, it is necessary to identify what are the core functions for a sustainable future of a capital, on a regional scale. Inevitably, the reconfiguration of urban functions will change the population structure, for which all the policy making and urban planning should be developed based on specific urban identities, characteristics, and demands.

\section{What are the biggest challenges in urban village renewal? In recent years, has the "demolition-resettlement" policy had any adaptive changes?}

YU: Urban village is generated in the context of rapid land urbanization in China. The biggest restriction to some urban village renewal lies in that the administrative regime, the land ownership, and dwellers are still rural. However, this situation is hard to be changed due to high social and economic costs of turning the villagers collectiveowned land into state-owned land. There are also difficulties in transferring the rural residency status to urban one in that villagers will lose their allocated lands and the government has to pay for the costly land compensation and social insurance.

The significance of urban villages, which provide affordable dwellings to the migrates and contribute greatly to a city's inclusiveness, is much underestimated. Meanwhile, the depression of real estate industry makes less urban villages demolished for new housing development, resulting in that urban renewal, instead of overall 
reconstruction, becomes increasingly predominant with a higher emphasis on the consensus among plural agents.

In most cases, the sanitation problem, fire safety hazard, and the floating population administration and public security problem become the primary challenges to urban village renewal. On one hand, the built environment can be improved through dwelling reinforcement, illegal building demolition, and infrastructure enhancement; on the other hand, the community empowerment can be facilitated by engaging different groups of people and respecting their real willingness and needs. In addition, adaptive land policies should be introduced to lead the reorientation of public service in order to better meet the contemporary demands of the whole society. For example, part of the ownership of collective-owned land could be remained in renewals, which can be run by the local government and gain profits from providing lowprice places for emerging enterprises, innovative industries, and start-up communities.

The conservation of cultural characteristics and the villagers' common memories is another important issue which should be considered in the planning phases. However, in fact, cultural factors are often less reflected in resulting plans. To urban planners and designers, how to continue the local cultural characteristics in the urban renewal is a must which needs to be further explored in their future efforts.

\section{What are the challenges in old residential area renewal? Could you please give some suggestions to urban planners or designers in responding to these challenges?}

YU: The challenges of old residential area renewal come from three aspects.

First, the issues regarding the population structure and social relationship are often complicated. In some old residential area located at the center of Beijing, for instance, most dwellers are aging seniors and young white-collar workers, whose extremely different backgrounds and needs challenge the coordination in urban renewal. There are some recommended practices which have been proved to be feasible, such as community kitchens providing meals for both the senior and the young workers, and mutual-help mechanisms between the senior and the youth, or among the seniors. For the latter, a new point-based system has been introduced, in which points can be earned by taking care of the seniors and paid when in need of help.

Second, issues related to housing property in old residential areas are often complicated. After the housing property reform in China, the renewal of some residential areas built or invested by work units is hindered by the complicated property ownerships, including private household, workunit-owned, and co-owned ones. For this reason, problems will emerge such as who bears the costs of the everyday maintenance and management and who gains the profits from the renewed housing property. Worse, in some residential areas, succeeding management and facility improvement is hard to realize or even abandoned as the original work units no longer exist and there is no new capitals to invest in.

Third, the mechanism of old residential area renewal is to be improved. By now, there are contradictions in optimizing public services and creating green spaces with meeting the standard of housing plot ratio. Moreover, according to the existing resettlement policies, new housing for the original dwellers moving back requires a huge amount of compensation that would cause a big debt to the government, leaving whom no choice but introducing partnership models or bundling commercial developments. 
How is the community engagement in old residential area renewal? How to meet dwellers' needs in the renewals?

YU: We are glad to notice that public engagement in public services and affairs is enhancing along with China's social and economic development the increased visits to urban planning exhibition halls is an evidence.

Meanwhile, thanks to the enhanced rational understanding to domestic issues and governments' flexible administration and policies, the consensus among plural agents makes rapid progress.

In China, community engagement in old residential area renewal has widely promoted with more and more social recognition, greatly due to the success of organization and coordination with a shift from top-bottom decision-making and implementing towards governmentcitizen collaboration. A longer-time preparation for renewal is also needed to allow for more conductive community engagement.

Public engagement can be facilitated through strategic actions. First, it is important to motivate the public interests with proper methods. For instance, activities and events such as collecting children's paintings on "my dream city" and online forums for free discussion on future vision of the cities can be introduced to foster dwellers' sense of ownership.

Second, urban planners should understand dwellers' demands and lifestyles, and try to make the dwellers believe that community renewal is a business that only can be promoted through a collaboration between the residents and designers. A responsibility system is proposed in many cities such as Beijing, through which a long-term relationship between planners and dwellers is established, contributing to both the enhancement of their mutual trust and the promotion of community renewal.

Third, more creative initiatives on community management need to be developed. In old residential area renewals, many conflicts can be resolved through proper administrative approaches and establishment of harmonious social relationships. I would suggest to learn from the success of neighborhood committee, a unique organization of social administration in China. Different from the owner committee or property management committee that are made up of stakeholders, the neighborhood committee is an organization to enhance the community members' well-being. Thus, it works better in establishing social networks and community management. LAF 